\title{
Pengobatan mastitis pada sapi perah Peranakan Friesian Holstein di UPT Pembibitan Ternak dan Hijauan Makanan Ternak Kediri
}

\section{Mastitis treatment for Peranakan Friesian Holstein dairy cattle at UPT Pembibitan Ternak dan Hijauan Makanan Ternak Kediri}

\author{
Mega Mila Panjuni ${ }^{1}$, Farizal Abdi Firdaus ${ }^{2}$, Erfan Kustiawan ${ }^{1}$, Hariadi \\ Subagja ${ }^{1}$, dan Theo Mahiseta Syaniar ${ }^{1 *}$ \\ ${ }^{1}$ Program Studi Produksi Ternak, Jurusan Peternakan, Politeknik Negeri Jember, Jl. \\ Mastrip 164, Jember 68101 \\ ${ }^{2}$ UPT Pembibitan Ternak dan Hijauan Makanan Ternak Kediri, Jl. Raya Branggahan, \\ Krajan, Branggahan, Kecamatan Ngadiluwih, Kediri 64171 \\ *Email Koresponden: mahiseta@polije.ac.id
}

\begin{abstract}
Abstrak. Studi ini bertujuan untuk mengevaluasi pengobatan mastitis pada sapi perah di UPT Pembibitan Ternak dan Hijauan Makanan Ternak Kediri. Studi ini merupakan studi kasus di lapangan yang dilakukan dengan cara melakukan pengobatan secara langsung kepada ternak yang terinfeksi mastitis, observasi, wawancara, dokumentasi, dan studi pustaka. Pelaksanaan pengobatan dilakukan di UPT Pembibitan Ternak dan Hijauan Makanan Ternak Kediri selama 7 hari yaitu pada tanggal 14 September sampai dengan 20 September 2020. Penanganan terhadap ternak yang terdiagnosa mastitis di UPT Pembibitan Ternak dan Hijauan Makanan Ternak Kediri perlu dilakukan berupa pengobatan karena terjadi penurunan rata-rata produksi susu sebesar 5,1 liter/hari. Pengobatan mastitis dilakukan dengan menggunakan Biomycin M, Vet-Oxy La, dan Phenylject. Pengobatan tersebut menunjukkan pengaruh yang baik terhadap sapi perah. Hal tersebut ditandai dengan sembuhnya ternak yang terjangkit mastitis dan meningkatnya kembali produksi susu sebesar 1,6 liter/hari setelah dilakukan pengobatan. Hasil pengamatan dapat disimpulkan bahwa pengobatan dengan menggunakan Biomycin M, Vet-Oxy La, dan Phenylject dapat menyembuhkan mastitis pada sapi perah.
\end{abstract}

Kata kunci: biomycin M, mastitis, Phenylject, sapi perah, Vet-Oxy La

Abstract. This study aimed to evaluate the mastitis treatment to dairy cows at UPT Pembibitan Ternak dan Hijauan Makanan Ternak Kediri. This study was a case study that conducted by direct treatment to the cattle infected mastitis, observation, interviews, documentation, and literature study. The treatment was carried out at the UPT Pembibitan Ternak dan Hijauan Makanan Ternak Kediri for 7 days since 14 September to 20 September 2020. Mastitis treatment at the UPT Pembibitan Ternak dan Hijauan Makanan Ternak Kediri needed to be done because there was a decreasing milk production of 5.1 liters/day. Mastitis treatment did use Biomycin M, Vet-Oxy La, and Phenylject. The treatment showed a good effect on dairy cows infected. This was indicated by the recovery of cows infected and increased milk production of 1.6 liters/day after treatment. The results of observations could be concluded that treatment using Biomycin M, Vet-Oxy La, and Phenylject succeeded to cure mastitis in dairy cows.

Keywords: biomycin M, mastitis, Phenylject, dairy cow, Vet-Oxy La 
Panjuni et al.

ANIMPRO: Conference of Applied Animal Science Proceeding Series

\section{PENDAHULUAN}

Kesadaran masyarakat akan kandungan gizi yang lengkap pada susu menyebabkan permintaan susu di masyarakat terus meningkat. Namun, peningkatan kebutuhan susu tersebut belum mampu diimbangi penyediaannya khususnya oleh pihak UPT Pembibitan Ternak dan Hijauan Makanan Ternak yang memiliki salah satu jenis pelayanan kepada masyarakat sekitar yaitu menjual hasil ternak berupa susu sapi perah. Penghambat dalam peningkatan produksi susu salah satunya dipengaruhi oleh manajemen pemeliharaan yang kurang baik terutama pada manajemen kesehatan. Salah satu ancaman penyakit yang sering menginfeksi sapi perah saat laktasi adalah mastitis sehingga menyebabkan kerugian ekonomi yang sangat besar bagi peternakan sapi perah di seluruh dunia (Bannerman \& Wall, 2005).

Mastitis adalah istilah yang digunakan untuk radang yang terjadi pada ambing, baik bersifat akut, subakut ataupun kronis, terdapat peningkatan jumlah sel di dalam air susu dan perubahan fisik maupun kandungan nutrien air susu, disertai dengan atau tanpa adanya perubahan patologis pada kelenjar mamae (Subronto, 2003). Penyakit mastitis secara umum disebabkan oleh berbagai jenis bakteri antara lain Streptococcus agalactiaea, S. disgalactiae, S. uberis, S. zooepidermicus, Staphylococcus aureus, Escherichia coli, Enterobacter aerogenes, dan Pseudomonas aeruginosa serta Mycoplasma sp., Candida sp., Geotrichum sp. dan Nocardia sp. pada kasus mastitis mikotik (Akoso, 1996; Hastiono, 1984). Mastitis pada sapi perah dapat menyebabkan penurunan produksi susu mencapai $15 \%$ hingga $30 \%$ per sapi per laktasi (Subronto, 2003). Pengobatan mastitis pada sapi perah sangat penting dilakukan di usaha peternakan sapi perah khususnya di UPT Pembibitan Ternak dan Hijauan Makanan Ternak Kediri. Hal tersebut dimaksudkan untuk menjaga kestabilan kuantitas maupun kualitas produksi susu yang dihasilkan. Oleh karena itu, studi ini dilakukan bertujuan untuk mengevaluasi pengobatan mastitis pada sapi perah di UPT Pembibitan Ternak dan Hijauan Makanan Ternak Kediri.

\section{MATERI DAN METODE}

Waktu, Tempat dan Materi

Pelaksanaan kegiatan pengamatan dilaksanakan pada bulan September 2020 di UPT Pembibitan Ternak dan Hijauan Makanan Ternak Kediri, yang berlokasi di Jalan Raya Branggahan, Krajan, Branggahan, Kecamatan Ngadiluwih, Kabupaten Kediri. Materi yang digunakan adalah sapi perah Peranakan Friesian Holstain (PFH) dengan masa laktasi ke-5 yang menderita mastitis sebanyak 1 ekor di UPT Pembibitan Ternak dan Hijauan Makanan Ternak Kediri. Obat-obatan yang digunakan yaitu Biomycin M, Vet-Oxy La, dan Phenylject. Alat pendukung yang digunakan meliputi peralatan dokumentasi, alat tulis, alat suntik, dan gelas Erlenmeyer.

\section{Metode Pelaksanaan}

Metode pengamatan menggunakan metode kualitatif, pemilihan sampel berdasarkan kriteria ternak yang menderita mastitis. Pengambilan data dilakukan dengan cara pemeriksaan mastitis pada sapi perah melalui kegiatan inspeksi dan palpasi ternak, mengumpulkan data primer yang diperoleh melalui pengobatan secara langsung kepada sapi perah yang terinfeksi mastitis, melakukan wawancara, observasi, dan dokumentasi. Data sekunder yaitu recording produksi susu sapi perah sebelum mastitis, saat mastitis, dan setelah mastitis.

\section{Parameter Pengamatan}

Gejala mastitis. Pengamatan gejala mastitis dilakukan melalui kegiatan inspeksi dan palpasi ternak secara langsung pada sapi perah yang diidentifikasi terjangkit mastitis.

Pengobatan dan Pencegahan mastitis. Pengobatan mastitis dilakukan secara langsung pada sapi perah yang terjangkit mastitis yaitu pada sapi dengan periode laktasi ke- 5 dan nomor eartag 087. Selama pengobatan juga dilakukan pengamatan terhadap proses penyembuhan sapi dari mastitis, perubahan secara fisik pada ambing maupun susu yang dihasilkan. 
Produksi susu. Produksi susu diketahui dari data recording produksi susu sapi perah Friesian Holstain pada bulan September 2020 di UPT Pembibitan Ternak dan Hijauan Makanan Ternak Kediri.

\section{Analisis data}

Data yang diperoleh baik data primer maupun data sekunder dianalisis dengan metode deskriptif.

\section{HASIL DAN PEMBAHASAN}

\section{Gejala Mastitis pada Sapi Perah Peranakan FH}

Pemeriksaan mastitis rutin dilakukan setiap harinya oleh pegawai kandang UPT Pembibitan Ternak dan Hijauan Makanan Ternak Kediri. Pemeriksaan tersebut bertujuan agar penanganan dan pengobatan sapi yang menderita mastitis dapat segera ditangani agar tidak menimbulkan kerugian yang berkelanjutan. Gambar sapi perah yang terindikasi mastitis seperti yang disajikan pada Gambar 1. Berikut identitas ternak yang terindikasi mastitis:

$\begin{array}{ll}\text { Eartage } & : 087 \\ \text { Bangsa Sapi } & : \text { Sapi Perah Friesian Hostain }(\mathrm{FH}) \\ \text { Umur } & : 7 \text { tahun } \\ \text { Warna } & : \text { Hitam Putih } \\ \text { Jenis Kelamin } & : \text { Betina }\end{array}$

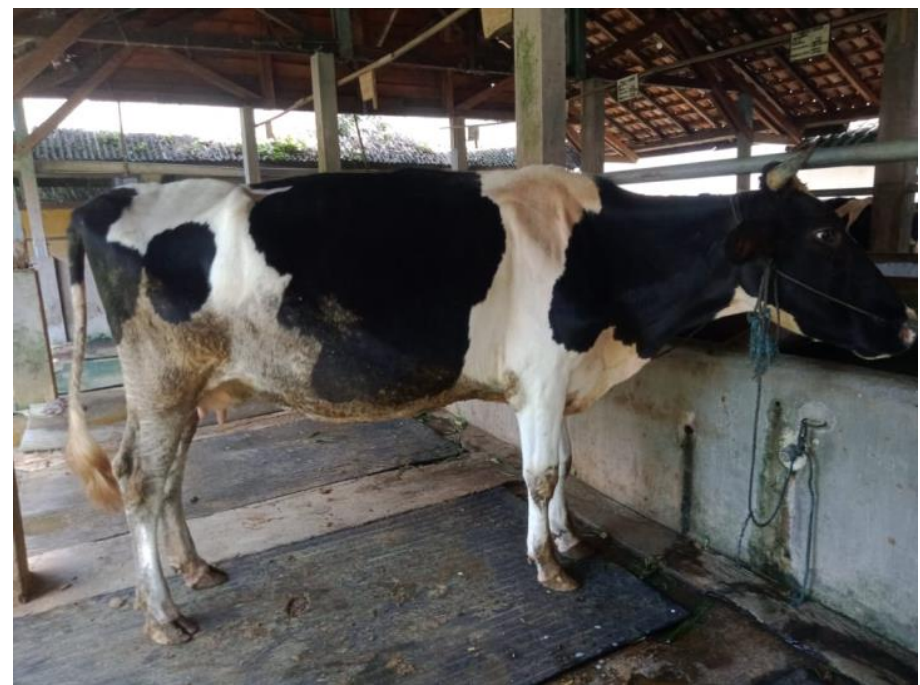

Gambar 1. Sapi perah induk 087 yang terindikasi mastitis.

Indikasi mastitis terlihat melalui pemeriksaan fisiologis, inspeksi dan palpasi yang dilakukan pada sapi. Hasil pemeriksaan fisiologis sapi yang terindikasi mastitis dapat dilihat pada Tabel 1. Hasil pemeriksaan fisiologis menunjukkan bahwa sapi yang terindikasi mastitis mengalami peningkatan suhu tubuh sebesar $0,8^{\circ} \mathrm{C}$. Peningkatan suhu tubuh sapi juga diiringi dengan peningkatan frekuensi pernafasan dan denyut nadi sapi. Adanya perubahan kondisi fisiologis sapi ini diakibatkan adanya peradangan pada ambing. Peradangan pada ambing disebabkan oleh adanya mikroorganisme khususnya bakteri mastitis baik bakteri gram positif maupun bakteri gram negatif yang masuk melalui puting sapi pada saat pemerahan karena sphincter puting yang membuka kemudian menginfeksi ambing sapi tepatnya di alveoli.

Selain dilakukan pemeriksaan fisiologis, dilakukan pula inspeksi dan palpasi ambing sapi serta pemeriksaan susu yang dihasilkan untuk memastikan indikasi mastitis yang terjadi. Hasil inspeksi ambing menunjukkan terjadinya pembengkakan pada ambing sapi sebelah kanan, puting bagian belakang menggerenjal dan terasa sakit ketika diperah. Rasa sakit tersebut terlihat dari reaksi sapi yang tidak tenang ketika dilakukan pemerahan. Berdasarkan hasil tersebut, sapi perah induk 087 diagnosis mengalami mastitis klinis. Mastitis klinis adalah penyakit mastitis yang mempunyai 
Panjuni et al.

ANIMPRO: Conference of Applied Animal Science Proceeding Series

gejala klinis yang jelas pada ambing ditandai pembengkakan dan panas ketika diraba, tetapi mastitis subklinis tidak mempunyai gejala sama sekali (Ahmad \& Gholib, 2016).

Tabel 1. Hasil pemeriksaan fisiologis sapi perah yang terindikasi mastitis.

\begin{tabular}{|c|c|c|c|}
\hline No. & Keterangan & Hasil pengukuran & Kondisi normal \\
\hline 1. & Suhu tubuh & $39,8^{\circ} \mathrm{C}$ & $\begin{array}{l}38-39{ }^{\circ} \mathrm{C} \text { (Santosa, Tanuwiria, Yulianti, \& } \\
\text { Suryadi, 2012) }\end{array}$ \\
\hline 2. & Frekuensi pernapasan & 40 kali/menit & $\begin{array}{l}15-35 \text { kali/menit (Cockcroft \& Jackson, } \\
2004 \text { ) }\end{array}$ \\
\hline 3. & Frekuensi denyut nadi & $90 \mathrm{kali} / \mathrm{menit}$ & $\begin{array}{l}\text { 40-70 kali/menit (Kubkomawa, Emenalom, } \\
\text { \& Okoli, 2015) }\end{array}$ \\
\hline
\end{tabular}

Pemeriksaan selanjutnya yang dilakukan adalah pemeriksaan fisik pada susu yang dihasilkan oleh sapi induk 087. Hasil pemeriksaan fisik susu menunjukkan terjadinya perubahan warna menjadi kekuningan dan encer. Menurut (Riyanto et al., 2017), indikasi sapi perah terinfeksi mastitis dapat dilihat dari tanda-tanda warna susu menjadi putih kemerahan atau putih pucat. Hasil pengamatan menunjukkan warna susu berwarna kuning pekat. Hal ini disebabkan karena susu masih dalam proses pengumpalan dan tidak sampai mengalami pendarahan sehingga warna susu tidak kemerahan. Sapi yang terinfeksi mastitis juga terkadang menghasilkan susu menjadi pecah sehingga terlihat lebih encer (Direktorat Jenderal Peternakan dan Kesehatan Hewan, 2014). Hasil inspeksi dan palpasi sapi serta perbedaan warna susu dari sapi yang mengalami mastitis dapat dilihat pada Gambar 2.

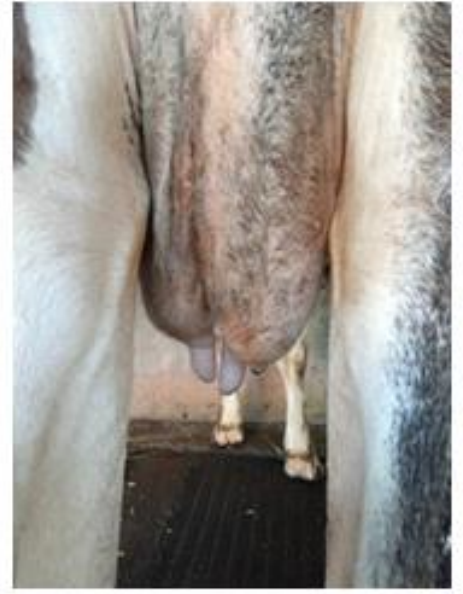

A

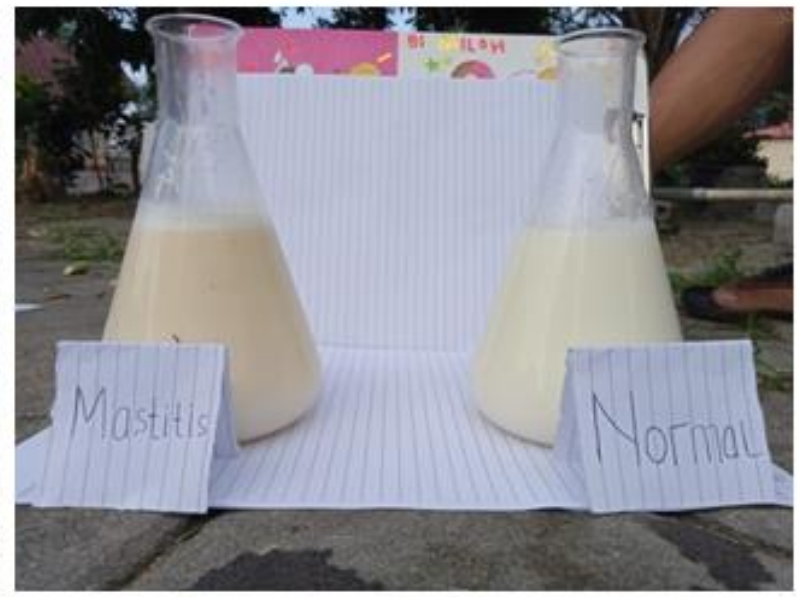

B

Keterangan:

$A=$ Ambing sapi mastitis membengkak

$\mathrm{B}=$ Perbedaan warna susu mastitis dan normal

Gambar 2. Hasil Inspeksi, Palpasi, dan Pemeriksaan Susu pada Sapi yang Mengalami Mastitis

Timbulnya mastitis di UPT Pembibitan Ternak dan Hijauan Makanan Ternak Kediri disebabkan oleh banyaknya pegawai yang kurang mematuhi SOP yang telah ditetapkan seperti mencuci tangan sebelum melakukan pemerahan dan melakukan dipping sebelum maupun sesudah melakukan pemerahan. Hal tersebut menyebabkan bakteri patogen dapat masuk ke dalam lubang puting dan menyebabkan infeksi. Tangan pemerah merupakan salah satu sumber kontaminasi bakteri dalam susu dengan ditemukannya bakteri patogen seperti Staphylococcus aureus dan Escherichia coli (Handayani \& Purwanti, 2010). Menurut (Nurhayati \& Martindah, 2015) menyatakan bahwa kebersihan lingkungan dan jumlah kepemilikan ternak juga berasosiasi dan bermakna terhadap kejadian mastitis, artinya dengan kebersihan lingkungan yang jelek maka kejadian mastitis akan meningkat, demikian pula dengan jumlah kepemilikan ternak. 
Panjuni et al.

ANIMPRO: Conference of Applied Animal Science Proceeding Series

Kebersihan pemerah harus diutamakan karena melalui pemerah dapat terjadi penularan mastitis akibat kontak bakteri antara pemerah dan sapi yang diperah (Sudono, Rosdiana, \& Setiawan, 2003).

\section{Pengobatan dan Pencegahan Mastitis}

Sapi perah induk 087 dinyatakan positif menderita mastitis klinis berdasarkan hasil pemeriksaan fisiologis, inspeksi dan palpasi pada ternak, serta pemeriksaan fisik pada susu yang dihasilkan. Selanjutnya, sapi tersebut diberikan penanganan dan pengobatan mastitis secara cepat agar tidak bertambah parah dan menginfeksi sapi lainnya. Pengobatan mastitis pada sapi perah di UPT Pembibitan Ternak dan Hijauan Makanan Ternak Kediri dapat disajikan pada Tabel 2.

Tabel 2. Pengobatan Mastitis pada Sapi Perah

\begin{tabular}{|c|c|c|c|c|c|c|}
\hline No. & Nama Obat & Dosis & $\begin{array}{l}\text { Jumlah } \\
\text { Treatment }\end{array}$ & $\begin{array}{c}\text { Tanggal } \\
\text { Pengobatan }\end{array}$ & Kandungan & Keterangan \\
\hline 1. & $\begin{array}{l}\text { Biomymicin } \\
\text { M }\end{array}$ & $5 \mathrm{ml}$ & 3 kali & $\begin{array}{l}14 \text { September } \\
2020\end{array}$ & $\begin{array}{l}\text { Amoxycillin } \\
\text { tryhidrate } 100 \\
\text { mg } \\
\text { Neomycin } \\
\text { sulphate } 50 \mathrm{mg}\end{array}$ & Intramammary \\
\hline 2. & Vet-Oxy La & $10 \mathrm{cc}$ & 1 kali & $\begin{array}{l}16 \text { September } \\
2020\end{array}$ & $\begin{array}{l}\text { Oxytetracycline } \\
200 \mathrm{mg}\end{array}$ & Intramuscular \\
\hline 3. & Phenylject & $10 \mathrm{ml}$ & 1 kali & $\begin{array}{l}20 \text { September } \\
2020\end{array}$ & $\begin{array}{l}\text { Phenylbutazone } \\
200 \mathrm{mg}\end{array}$ & Intramuscular \\
\hline
\end{tabular}

Pengobatan mastitis klinis dilakukan dengan memberikan Biomycin M, Vet-Oxy La dan Phenylject. Biomycin $\mathrm{M}$ merupakan obat untuk sapi perah mastitis pada masa laktasi yang diberikan selama 3 hari dengan dosis 1 syringe $(5 \mathrm{ml})$ per kuartir ambing. Setiap ml Biomycin $\mathrm{M}$ mengandung Amoxycillin tryhidrate $100 \mathrm{mg}$ dan Neomycin sulphate $50 \mathrm{mg}$. Pemberian Biomycin $M$ tergolong antibiotika berspektrum luas sehingga efektif untuk membunuh bakteri gram positif dan juga bakteri gram negarif misalnya $S$. uberis, Staphylococcus penicillinase negative, Haemophilus, Clostridium, Campylobacter Corynebacterium, E. coli, Erysipelothrix, Pasteurella, Streptococcus, Salmonella sp., Streptococcus dysgalactiae, dan Corynebacterium pyogenes. Kandungan neomycin sendiri efektif membunuh bakteri gram negatif yang antara lain Pasteurella, Salmonella, Haemophylus sp., E. coli, dan Klebsiella. Vet-Oxy La merupakan antibiotik injeksi long acting dengan waktu aktif selama 3 hari dengan kandungan Oxytetracycline $200 \mathrm{mg}$ untuk mengobati penyakit yang disebabkan oleh organisme seperti bakteri penyebab mastitis pada ternak perah. Vet-Oxy La diberikan sebanyak $10 \mathrm{cc}$ secara intramuscular. Phenylject merupakan obat antipiretik, analgesik, dan dan antiinflamasi. Pemberian Phenylject dilakukan secara intramuscular sebanyak $10 \mathrm{ml}$.

Susu hasil pemerahan dari sapi yang diberi antibiotik biomycin M dan Vet-Oxy La selama beberapa hari tidak boleh dikonsumsi terlebih dahulu karena akan menyebabkan terbentuknya residu pada susu. Ancaman potensial residu antibiotika dalam makanan dan susu terhadap kesehatan secara umum dibagi menjadi tiga kategori, yaitu aspek toksikologis, mikrobiologis, dan imunopatologis (Nurhayati \& Martindah, 2015).

Setelah dilakukan pengobatan mastitis selama 7 hari kemudian dilakukan inspeksi dan palpasi kembali pada sapi perah penderita mastitis. Hasil inspeksi dan palpasi ternak menunjukkan bahwa kondisi ambing sapi sudah kembali normal, tidak terdapat pemengkakan, puting tidak menggerenjal, dan kondisi warna susu yang kembali menjadi putih. Hal tersebut terjadi akibat pemberian antibiotik dapat menghasilkan efek bakterisida sehingga bakteri pathogen akan berkurang dan sel epitel alveoli akan mengalami perbaikan yang menyebabkan kondisi kelenjar susu dan kuartir ambing berangsur-angsur membaik dan kembali normal. Sesuai dengan pendapat Navyanti \& Adriyani (2015) yang menyatakan bahwa susu yang normal berwarna putih 
kebiruan hingga agak kuning kecoklatan. Hasil Inspeksi dan Palpasi Ternak serta Pemeriksaan Susu Setelah Pengobatan disajikan pada Gambar 3.

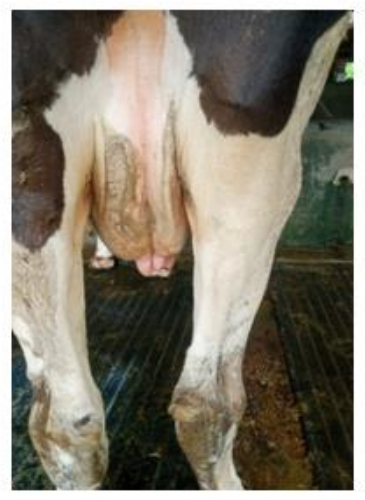

A

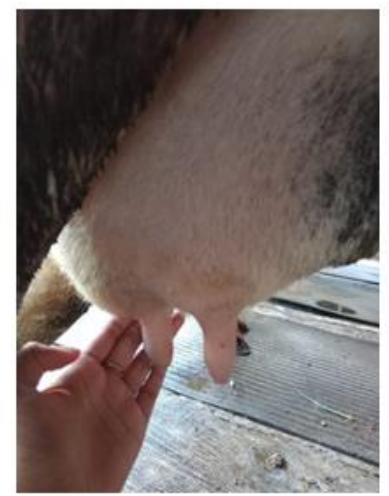

B

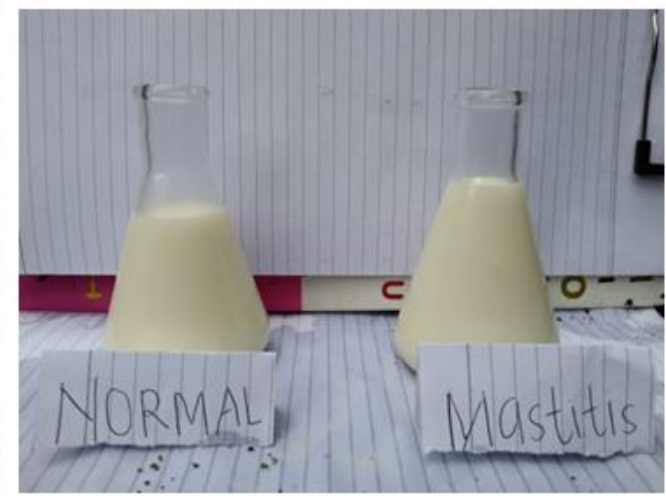

$\mathrm{C}$

Keterangan:

$A=$ Ambing sapi sebelah kanan kemali normal dan tidak membengkak

$\mathrm{B}=$ Puting sapi tidak menggerenjal

$\mathrm{C}=$ Warna susu kembali normal

Gambar 3. Hasil Inspeksi dan Palpasi Ternak serta Pemeriksaan Susu Setelah Pengobatan

Pencegahan yang sebaiknya dilakukan untuk memperkecil kasus mastitis yang terjadi di UPT Pembibitan Ternak dan Hijauan Makanan Ternak Kediri antara lain dengan selalu menerapkan praktik hygiene dan SOP pemerahan. Pekerja harus selalu memperhatikan kebersihan tubuhnya dan mencuci tangan sesaat sebelum memasuki area kandang untuk memerah sapi maupun ketika berpindah dari sapi satu ke sapi yang lainnya saat pemerahan. Pemerahan juga harus dilakukan hingga tuntas dan diakhiri dengan melakukan teat dipping. Salah satu upaya pengendalian mastitis yaitu mencelup puting (teat dipping) dengan menggunakan antiseptik setelah pemerahan karena ini merupakan strategi manajemen yang baik untuk mengurangi laju infeksi baru intramammary pada sapi perah (Rahayu, 2007). Selain itu, penyuntikan antibiotik sebaiknya dilakukan pada sapi perah periode kering untuk menekan kasus mastitis pada saat periode laktasi (Bhutto, Murray, \& Woldehiwet, 2011).

\section{Produksi Susu}

Mastitis merupakan salah satu penyakit radang ambing yang menyerang sapi perah dan berdampak negatif sehingga menyebabkan kerugian bagi peternak. Kerugian tersebut ditimbulkan akibat menurunnya produksi susu. Penurunan produksi susu berdampak pada kerugian ekonomi. Kerugian ekonomi yang diakibatkan mastitis berupa (1) penurunan produksi susu per kuartir per hari antara 9 hingga 45,5\%; (2) penurunan kualitas susu yang mengakibatkan penolakan susu mencapai $30-40 \%$; (3) penurunan kualitas hasil olahan susu dan (4) peningkatan biaya perawatan dan pengobatan serta pengafkiran ternak lebih awal (Sudarwanto, 1999). Fluktuasi produksi susu pada sapi perah penderita mastitis ketika sebelum, saat mastitis, dan setelah pengobatan dapat dilihat pada Gambar 4.

Sapi perah yang menderita mastitis di UPT Pembibitan Ternak dan Hijauan Makanan Ternak Kediri mengalami penurunan produksi susu saat menderita mastitis. Penurunan sekresi susu terjadi karena berkurangnya jumlah kelenjar yang aktif dan terjadi atrofi kelenjar alveoli. Penurunan tersebut sebesar 5,1 liter/hari. Kemudian setelah mendapatkan pengobatan dapat diketahui bahwa pengobatan yang dilakukan dengan menggunakan Biomymicin M, Vet-Oxy La, dan Phenylject pada sapi perah penderita mastitis memberikan pengaruh yang baik. Hal tersebut ditunjukkan dengan peningkatan kembali secara perlahan dan bertahap dengan rata-rata peningkatan produksi susu sebesar 1,6 liter/hari. Peningkatan kembali produksi susu mengindikasikan keberhasilan pengobatan yang dilakukan. Kesembuhan kuartir pada sapi perah 
penderita mastitis secara otomatis akan meningkatkan jumlah produksi susu yang dihasilkan (Riyanto et al., 2017). Namun demikian, peningkatan produksi susu setelah dilakukan pengobatan tidak terjadi secara signifikan melainkan secara perlahan dan bertahap karena sapi perah membutuhkan waktu dan proses untuk kembali pada produksi susu normal.

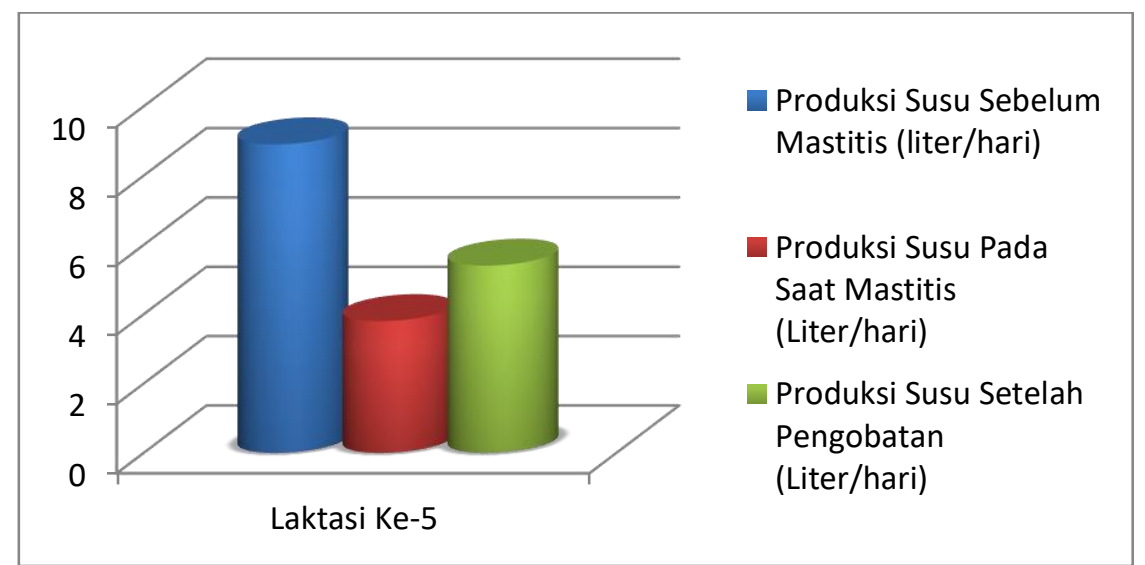

Gambar 4. Fluktuasi produksi susu pada sapi perah penderita mastitis.

\section{KESIMPULAN}

Evaluasi pengobatan mastitis di UPT Pembibitan Ternak dan Hijauan Makanan Ternak menggunakan Biomymicin M, Vet-Oxy La, dan Phenylject efektif dapat menyembuhkan ternak yang menderita mastitis klinis. Hal tersebut ditandai dengan peningkatan kembali produksi susu secara perlahan dan bertahap sebesar 1,6 liter/hari setelah sebelumnya mengalami penurunan produksi hingga 5,1 liter/hari. Pencegahan yang sebaiknya dilakukan untuk memperkecil kasus mastitis yang terjadi di UPT Pembibitan Ternak dan Hijauan Makanan Ternak Kediri antara lain dengan selalu menerapkan praktik hygiene dan SOP pemerahan.

\section{DAFTAR PUSTAKA}

Ahmad, R. Z., \& Gholib, D. (2016). Mastitis mikotik akibat terinfeksi candida spp dan trichosporon spp pada peternakan sapi perah di Bogor, Bandung dan Jakarta. J. Veteriner Maret, 17(1), 119-125.

Akoso, B. T. (1996). Kesehatan sapi. Kanisius, Yogyakarta.

Bannerman, D. D., \& Wall, R. J. (2005). A novel strategy for the prevention of Staphylococcus aureusinduced mastitis in dairy cows. Information Systems for Biotechnology News Report. Virginia Tech University. USA, 1-4.

Bhutto, A. L., Murray, R. D., \& Woldehiwet, Z. (2011). The effect of dry cow therapy and internal teatsealant on intra-mammary infections during subsequent lactation. Research in Veterinary Science, 90(2), 316-320.

Cockcroft, P., \& Jackson, P. (2004). Clinical examination of the abdomen in adult cattle. In Practice, 26(6), 304-317.

Handayani, K. S., \& Purwanti, M. (2010). Kesehatan ambing dan higien pemerahan di peternakan sapi perah desa pasir buncir kecamatan caringin. Jurnal Penyuluhan Peternakan, 5(1).

Hastiono, S. (1984). Mastitis mikotik, radang kelenjar susu oleh cendawan pada ternak perah. Wartazoa, 1(4), 9-12.

Direktorat Jenderal Peternakan dan Kesehatan Hewan. (2014). Manual Penyakit Hewan Mamalia Cetakan Ke-2. Kementerian Pertanian Republik Indonesia.

Kubkomawa, I. H., Emenalom, O. O., \& Okoli, I. C. (2015). Body condition score, rectal temperature, respiratory, pulse and heart rates of tropical indigenous zebu cattle. Review. Int. J. Agric. Innovations I\& Res, 4(3), 448-453.

Navyanti, F., \& Adriyani, R. (2015). Higiene sanitasi, kualitas fisik dan bakteriologi susu sapi segar perusahaan susu x di Surabaya. Jurnal Kesehatan Lingkungan, 8(1), 36-47.

Nurhayati, I. S., \& Martindah, E. (2015). Pengendalian mastitis subklinis melalui pemberian antibiotik 
saat periode kering pada sapi perah. Wartazoa, 25(2), 65-74.

Rahayu, I. D. (2007). The sensitivity of Staphylococcus aureus as Mastitis Pathogen Bacteria Into Teat Dipping Antiseptic in Dairy Cows. Jurnal Protein, 14(1).

Riyanto, J., Sunarto, S., Hertanto, B. S., Cahyadi, M., Hidayah, R., \& Sejati, W. (2017). Produksi dan Kualitas Susu Sapi Perah Penderita Mastitis yang Mendapat Pengobatan Antibiotik. Sains Peternakan: Jurnal Penelitian IImu Peternakan, 14(2), 30-41.

Santosa, U., Tanuwiria, U. H., Yulianti, A., \& Suryadi, U. (2012). Pemanfaatan kromium organik limbah penyamakan kulit untuk mengurangi stres transportasi dan memperpendek periode pemulihan pada sapi Potong. JITV, 17(2), 132-141.

Subronto. (2003). IImu Penyakit Ternak (Mamalia) Edisi Kedua. Yogyakarta: Gadjah Mada University Press.

Sudarwanto, M. (1999). Usaha peningkatan produksi susu melalui program pengendalian mastitis subklinis. Orasi Ilmiah, 22.

Sudono, A., Rosdiana, R. F., \& Setiawan, B. S. (2003). Beternak sapi perah secara intensif. Agromedia Pustaka. Jakarta. 